\title{
Perbandingan Derajat Hiperemis Pascabedah Pterigium Inflamasi antara Teknik Lem Fibrin Otologus dan Teknik Jahitan
}

\author{
Maula Rifada, ${ }^{1}$ Loekman Prawirakoesoema, ${ }^{1}$ Nadjwa Zamalek Dalimoenthe, ${ }^{2}$ Sutarya Enus ${ }^{1}$ \\ ${ }^{1}$ Departemen Ilmu Kesehatan Mata Fakultas Kedokteran Universitas Padjadjaran-Rumah Sakit Mata \\ Cicendo Bandung ${ }^{2}$ Departemen Patologi Klinik Fakultas Kedokteran Universitas Padjadjaran \\ Rumah Sakit Dr. Hasan Sadikin Bandung
}

\begin{abstract}
Abstrak
Tandur konjungtiva bulbi merupakan baku emas pada pembedahan pterigium yang secara umum metode penempelannya dengan menggunakan jahitan, namun memiliki beberapa kekurangan, di antaranya waktu pembedahan cukup lama, menimbulkan reaksi inflamasi, dan kemungkinan komplikasi. Saat ini dikembangkan penggunaan lem fibrin untuk penempelan tandur konjungtiva bulbi sebagai alternatif prosedur pengganti jahitan. Penelitian ini bertujuan untuk mengetahui derajat hiperemis pascabedah pterigium inflamasi antara teknik lem fibrin otologus (LFO) dan teknik jahitan. Penelitian ini merupakan uji klinis acak terkontrol tersamar tunggal yang dilaksanakan di Pusat Mata Nasional Rumah Sakit Mata Cicendo Bandung dari bulan Oktober-Desember 2010. Subjek penelitian dibagi menjadi dua kelompok secara acak dan hasilnya terdapat 12 penderita kelompok LFO dan 14 penderita kelompok jahitan. Pemantauan dilakukan pada minggu pertama, kedua, dan keempat pascabedah serta dilakukan pengambilan foto lampu celah biomikroskop digital. Benang jahitan disamarkan menggunakan perangkat lunak penyunting foto dan satu orang pengamat menilai secara objektif derajat hiperemis pada foto digital. Analisis statistik dilakukan menggunakan Uji Mann Whitney. Hasil penelitian menunjukkan bahwa derajat hiperemis secara bermakna lebih kecil pada minggu pertama, kedua, dan keempat pada kelompok teknik LFO (derajat hiperemis 2,5; 2; dan 1,5) dibandingkan dengan kelompok teknik jahitan (derajat hiperemis 4; 3; dan 2) $(p<0,05)$. Simpulan, penggunaan LFO untuk melekatkan tandur konjungtiva bulbi pada pembedahan pterigium inflamasi menghasilkan derajat hiperemis yang lebih kecil dibandingkan dengan penggunaan jahitan. [MKB. 2013;45(3):174-9]
\end{abstract}

Kata kunci: Lem fibrin otologus, pterigium inflamasi

\section{Comparison of Hyperemia Degree between Autologous Fibrin Glue and Suture Technique Post Inflammed Pterygium Surgery}

\begin{abstract}
Conjunctival autograft is the gold standard in pterygium surgery which is regularly secured with suture, but this method has few drawbacks of prolonged operating time, provoke ocular inflammation and potential risk for suture related complication. The use of fibrin glue has become an alternative procedure in conjuntival graft transplantation. The aim of this study was to compare hyperemia degree post inflamed pterygium surgery between autologous fibrin glue (AFG) and suture technique. This was a randomized, controlled, single blind clinical trial that conducted in National Eye Center, Cicendo Eye Hospital Bandung from October-December 2010. Subjects were randomly assigned to two groups and as result 12 patients belong to AFG group and 14 belong to suture group. Digital slit-lamp photographs were taken at 1 st week, 2nd week and 4th week postoperatively for observation. Sutures were masked using photo-editing software and one masked observers objectively graded the digital photograph for degree of hyperemia. Statistical analysis was performed using Mann Whitney Test. The results of this study showed that the degree of hyperemia was significantly lower in AFG group (hyperemia degree 2.5, 2 and 1.5) than in suture group (hyperemia degree 4, 3 and 2) at 1st week, 2nd week and 4th week post operatively $(p<0.05)$. In conclusion, the use of AFG for graft fixation in inflamed pterygium surgery produced significantly lower hyperemia degree. [MKB. 2013;45(3):174-9]
\end{abstract}

Key words: Autologous fibrin glue, inflammed pterygium

Korespondensi: R. Maula Rifada, dr., Sp.M, Departemen Ilmu Kesehatan Mata Fakultas Kedokteran Universitas PadjadjaranRumah Sakit Dr. Hasan Sadikin Bandung, telepon 0224210883 e-mail maulardmd@yahoo.com 


\section{Pendahuluan}

Pterigium merupakan suatu pertumbuhan jaringan fibrovaskular konjungtiva yang berbentuk segitiga yang secara aktif berproliferasi dan tumbuh dari area limbal konjungtiva menuju area kornea yang lebih sering terjadi pada area dengan paparan sinar matahari tinggi. Pterigium dapat dibedakan menjadi pterigium noninflamasi yang memiliki stroma tipis dengan vaskularisasi minimal dan pterigium inflamasi yang mempunyai penebalan stroma disertai banyak vaskularisasi. ${ }^{1}$

Penatalaksanaan pterigium dilakukan dengan teknik menggunakan pembedahan. Permasalahan pada penatalaksanaan pterigium ini yaitu terjadi tumbuh ulangnya jaringan fibrovaskular. Faktorfaktor yang berperan terjadi tumbuh ulang antara lain jenis pterigium dengan jaringan fibrovaskular yang tebal (fleshy) dan terjadi inflamasi yang lebih lama pascabedah pterigium. Pemakaian dengan teknik tandurkonjungtivabulbi otografmerupakan baku emas atau gold standard penatalaksanaan pterigium dan memiliki angka tumbuh ulang yang rendah. ${ }^{1}$ Teknik penempelan tandur konjungtiva bulbi yang sering dipergunakan yaitu dengan jahitan, namun teknik ini mempunyai beberapa kekurangan antara lain waktu pembedahan yang cukup lama, reaksi inflamasi akibat jahitan yang dapat memperlambat proses penyembuhan luka, kemungkinan timbul komplikasi akibat jahitan, dan rasa tidak nyaman pada penderita. ${ }^{2-5}$

Penggunaan lem biologis seperti lem fibrin, mulai dikembangkan pada tindakan pembedahan pterigium sebagai pengganti jahitan. Lem fibrin memiliki dua komponen yaitu fibrinogen dan trombin. Kedua komponen tersebut digabungkan sesaat sebelum melakukan penempelan jaringan tandur konjungtiva sehingga akan menyerupai tahap terakhir proses pembekuan darah dengan terbentuk gumpalan fibrin yang stabil, membantu menghentikan proses perdarahan saat operasi, mengurangi hiperemis dan kemosis konjungtiva pascabedah, serta memiliki daya perekatan yang kuat. Penggunaan lem fibrin juga mengurangi waktu operasi serta mempercepat penempelan jaringan dan penyembuhan luka. ${ }^{6-9}$

Lem fibrin komersial terdiri atas komponen fibrinogen dan trombin darah donor (homologus), serta ditambahkan pula komponen aprotinin dari bovine. Proses pembuatan lem fibrin komersial telah diusahakan menghilangkan kemungkinan transmisi penyakit walaupun tidak dapat dicegah secara pasti. Selain itu, komponen bovine dapat menimbulkan reaksi imunologis. ${ }^{10,11}$ Lem fibrin komersial telah dipergunakan pada pembedahan pterigium dengan memberikan hasil waktu operasi yang lebih pendek, rasa nyeri yang lebih rendah, dan rasa lebih nyaman pascabedah dibandingkan dengan menggunakan teknik jahitan. ${ }^{3,5}$ Lem fibrin komersial belum tersedia di Indonesia, selain itu Food and Drugs Administration (FDA) belum memberikan izin untuk penggunaan pada bidang mata. $^{7}$

Lem fibrin otologus atau LFO tersebut mulai dikembangkan, yaitu berupa komponen fibrinogen dan trombin berasal dari darah penderita yang bersangkutan sehingga tidak ada risiko transmisi penyakit atau dapat bereaksi terhadap protein plasma. Penelitian eksperimental pada binatang telah dilakukan pada tahun 2007 dan 2008 atas kerjasama Laboratorium Sentral Pusat (Biologi Molekular) Fakultas Kedokteran (FK) Universitas Padjadjaran (Unpad), PT Bio Farma, Departemen Histologi FK Unpad, serta Departemen Patologi Klinik Rumah Sakit Dr. Hasan Sadikin Bandung. Penelitian itu membandingkan teknik jahitan dengan teknik LFO. Hasilnya didapatkan lama operasi lebih singkat dan perlekatan jaringan tandur konjungtiva lebih rapat menempel, serta lebih stabil yang dibuktikan secara mikroskopik tanpa celah luka pada teknik LFO. ${ }^{12,13}$ Pada tahun 2010 dilakukan uji klinis pada penderita pterigium noninflamasi dan didapatkan hasil derajat rasa nyeri dan derajat hiperemis yang lebih kecil pada teknik LFO dibandingkan dengan teknik jahitan. ${ }^{14}$ Tujuan penelitian ini adalah membandingkan derajat hiperemis pascabedah tandur konjungtiva bulbi antara teknik LFO dan teknik jahitan pada pterigium inflamasi.

\section{Metode}

Penelitian ini merupakan uji klinis acak terkontrol, tersamar tunggal. Penelitian dilakukan di Pusat Mata Nasional Rumah Sakit (RS) Mata Cicendo Bandung dan juga Departemen Patologi Klinik Fakultas Kedokteran Universitas Padjadjaran/ Rumah Sakit Dr. Hasan Sadikin Bandung pada penderita pterigium inflamasi yang memenuhi kriteria inklusi selama bulan Oktober-Desember 2010. Penelitian dilaksanakan setelah mendapat izin tertulis dari Komite Etik Penelitian Kesehatan Fakultas Kedokteran Universitas Padjadjaran (FKUP) Bandung. Pengambilan subjek penelitian dilakukan berdasarkan urutan datang penderita pterigium. Jenis tindakan operasi dilaksanakan secara acak dengan cara blok permutasi menjadi kelompok LFO sebanyak 12 orang dan kelompok jahitan sebanyak 14 orang.

Kriteria inklusi pada penelitian ini penderita pterigium primer inflamasi gradasi 2, ukuran pterigium pada daerah limbus sebesar dua jam (2 clock hours), usia 35-60 tahun, dan tidak terdapat kelainan hemostasis (mempunyai kadar fibrinogen, prothrombine time/PT, serta(activated 
prothrombine time/aPTT yang normal). Kriteria eksklusi terdapat infeksi mata, penderita diabetes melitus, glaukoma atau hipertensi okular, mata tersebut merupakan mata terbaik dan merupakan satu-satunya harapan agar dapat melihat (last eye), serta penderita yang menggunakan antikoagulan atau obat-obatan imunosupresan.

Pembuatan LFO dilaksanakan di Departemen Patologi Klinik Fakultas Kedokteran Unpad/ Rumah Sakit Dr. Hasan Sadikin Bandung dengan memisahkan komponen fibrinogen yang diproses berdasarkan teknik modifikasi Enus dkk. ${ }^{12}$ dan komponen trombin yang prosesnya berdasarkan teknik Armand J.Quick. ${ }^{15}$

Tindakan bedah dilaksanakan oleh seorang operator; tahap pertama dilakukan pengangkatan jaringan pterigium dan tahap kedua yang terbagi menjadi dua kelompok yaitu yang menggunakan LFO atau jahitan. Tahap pertama, pengangkatan jaringan pterigium dan perdarahannya dirawat dengan penekanan menggunakan spons absorber. Selanjutnya, dilakukan pengukuran luas defek konjungtiva dengan kaliper dan konjungtiva bulbi superior diberi tanda menggunakan kaliper sesuai luas defek. Sesudah itu, dilakukan penyuntikan konjungtiva bulbi superior dengan larutan lidokain $2 \%$ sehingga akan membentuk ballooning. Tahap berikutnya, dilakukan insisi pada konjungtiva bulbi superior pada daerah limbus, lalu dilakukan pemisahan jaringan konjungtiva dengan tenon secara tumpul. Jaringan konjungtiva ini yang sudah terpisah dari tenon sesudah itu digunting dengan menyertakan daerah limbus yang sesuai dengan ukuran yang sudah ditentukan. Tandur konjungtiva yang sudah digunting tadi diletakkan terbalik di atas kornea dengan bagian stroma menghadap ke atas. Selanjutnya, dilakukan tahap kedua yaitu penempelan tandur konjungtiva bulbi menggunakan teknik LFO atau jahitan.

Pada teknik lem fibrin dilakukan langkahlangkah sebagai berikut: 1) Dasar konjungtiva yang terbuka dikeringkan dengan memakai spons absorber; 2) Satu tetes komponen fibrinogen diletakkan pada sklera yang terbuka, sesudah itu ditambahkan satu tetes komponen trombin dan selanjutnya tandur konjungtiva dibalik dan diletakkan menutupi bagian sklera yang terbuka dengan segera. Bagian limbus tandur diletakkan pada bagian limbus resipien. Tandur konjungtiva kemudian diratakan permukaannya menggunakan bagian pinset yang tumpul sampai didapatkan aposisi yang baik antara tandur dan dasar tandur serta tepi tandur dengan tepi konjungtiva sehingga tidak terdapat lagi celah dan seluruh permukaan melekat. Lem fibrin yang berlebihan di tepi tandur dibersihkan menggunakan spons absorber dan jaringan tandur yang berlebih digunting sehingga besar tandur sesuai dengan defek konjungtiva.
Setelah tiga menit, spekulum dibuka kemudian penderita diminta melirik ke segala arah untuk melihat perlekatan tandur. Mata kemudian dibalut selama 24 jam.

Pada teknik jahitan ini dilakukan langkahlangkah: 1) Tandur konjungtiva diletakkan pada area sklera yang terbuka dengan cara membalikkan tandur menggunakan dua buah pinset anatomis dan bagian limbus tandur ditempatkan pada area limbus resipien; 2) Dilakukan penjahitan pada tepi tandur konjungtiva yang direkatkan pada bagian tepi konjungtiva resipien menggunakan benang nilon 10-0 sebanyak 8 jahitan kemudian simpul dipotong pendek dan tidak ditanam; 3) Spekulum dibuka dan mata dibalut tekan selama 24 jam.

Pascabedah diberikan tetes mata antibiotiksteroid (tobramisin-deksametason) 6 kali sehari dan antibiotik oral sefadroksil $500 \mathrm{mg}$ dua kali sehari.

Derajat hiperemis tandur konjungtiva bulbi dinilai berdasarkan gradasi: ${ }^{16} 0=$ tidak terlihat pembuluh darah yang berdilatasi dan berkelokkelok pada tandur; $1=$ terlihat 1 pembuluh darah yang berdilatasi dan berkelok-kelok, berwarna merah terang yang melintasi tepi tandur; $2=$ terlihat 2 pembuluh darah yang berdilatasi dan berkelokkelok, berwarna merah terang yang melintasi tepi tandur; $3=$ terlihat 3 pembuluh darah yang berdilatasi dan berkelok-kelok, berwarna merah terang yang melintasi tepi tandur; $4=$ terlihat $\geq 3$ pembuluh darah yang berdilatasi dan berkelokkelok, berwarna merah terang yang melintasi tepi tandur.

Derajat hiperemis dinilai pada pengamatan minggu pertama, kedua, dan keempat pascabedah pterigium. Untuk pemeriksaan segmen anterior dilakukan dengan mempergunakan lampu celah biomikroskop. Gambaran segmen anterior bola mata difoto dengan derajat intensitas cahaya dan pembesaran yang sama dengan menggunakan kamera digital yang terpasang pada lampu celah biomikroskop. Tindakan berikutnya dilakukan penyuntingan pada hasil foto digital kelompok jahitan untuk menghilangkan semua benang yang terlihat. Foto digital kemudan disimpan dan dimasukkan dalam bentuk slide pada program power point (Microsoft Office 2007). Selanjutnya seorang pengamat (dokter konsulen) yang tidak mengetahui kelompok penderita dan juga tidak melihat proses pengambilan, penyuntingan, dan penyimpanan foto, akan menilai derajat hiperemis sesuai dengan gradasi yang telah ditentukan pada setiap gambar yang ditampilkan dalam slide power point.

Uji nonparametrik oleh karena data penelitian merupakan skala ordinal menggunakan Uji Mann Whitney dan kemaknaan hasil uji bila $\mathrm{p}<0,05$. 
Tabel 1 Karakteristik Subjek Penelitian Kelompok LFO dan Kelompok Jahitan

\begin{tabular}{lcccc}
\hline Karakteristik & $\begin{array}{c}\text { Kelompok LFO } \\
(\mathbf{n = 1 2})\end{array}$ & $\begin{array}{c}\text { Kelompok } \\
\text { Jahitan } \\
(\mathbf{n = 1 4 )}\end{array}$ & $\begin{array}{c}\text { Total } \\
(\mathbf{n = 2 6 )}\end{array}$ & $\mathbf{p}$ \\
\hline Jenis kelamin & & & & \\
Laki-laki & 5 & 5 & 10 & $1,000^{*}$ \\
$\quad$ Perempuan & 7 & 9 & 16 & \\
Usia (tahun) & & & & \\
$\quad$ Rata-rata (SB) & $43,42(6.007)$ & $44,71(6.414)$ & $44,12(6.141)$ & $0,595^{* *}$ \\
\hline
\end{tabular}

Keterangan: $\mathrm{LFO}=$ lem fibrin otologus, $\mathrm{SB}=$ simpang baku, *berdasarkan Uji Exact Fischer, **berdasarkan Uji Mann Whitney

\section{Hasil}

Pemantauan pascabedah dilakukan dengan cara membuat foto menggunakan kamera digital yang terpasang pada lampu celah biomikroskop pada minggu pertama, minggu kedua, dan minggu keempat (Gambar). Foto-foto kelompok jahitan dilakukan dengan penyuntingan mempergunakan program Adobe Photoshop untuk menghilangkan gambaran benang, sesudah itu disimpan dalam slide power point untuk dapat dilakukan penilaian derajat hiperemis.

\section{Pembahasan}

Secara klinis pterigium dapat dibagi menjadi pterigium noninflamasi dan pterigium inflamasi. Telah dilaksanakan penelitian penggunaan LFO pada pterigium noninflamasi dan didapatkan bahwa derajat hiperemis yang lebih kecil secara bermakna pada kelompok LFO bila dibandingkan dengan kelompok jahitan pada pemantauan yang dilaksanakan pada minggu pertama, kedua, dan keempat pascabedah. ${ }^{14}$

Penelitian ini dilaksanakan pada pterigium inflamasi dengan hasil bahwa derajat hiperemis pascatandurkonjungtivabulbi kelompokLFOjuga lebih kecil bila dibandingkan dengan kelompok jahitan secara bermakna pada pemantauan yang dilaksanakan pada minggu pertama, kedua, dan minggu keempat. Srinivasan dkk. ${ }^{16}$ melakukan penelitian untuk membandingkan penggunaan lem fibrin (Tisseel) dengan teknik jahitan untuk melekatkan tandur konjungtiva pada pembedahan pterigium, diperlihatkan hasil derajat inflamasi yang bermakna lebih kecil pada kelompok yang mempergunakan lem fibrin bila dibandingkan dengan kelompok jahitan pada pemantauan bulan pertama dan ketiga pascabedah. Pada penelitian tersebut dibandingkan pula derajat perdarahan subkonjungtiva dan juga kestabilan tandur dengan hasil tidak terdapat perbedaan antara kelompok yang menggunakan lem fibrin dan jahitan.

Tabel 2 Perbandingan Derajat Hiperemis antara Kelompok LFO dan Kelompok Jahitan

\begin{tabular}{lccc}
\hline \multicolumn{1}{c}{ Pemantauan } & Kelompok LFO & Kelompok Jahitan & $\mathbf{p}^{*}$ \\
\hline Minggu pertama & 2,5 & 4 & 0,007 \\
$\quad$ Median & $0-4$ & $2-4$ & \\
$\quad$ Rentang & 2 & 3 & 0,008 \\
Minggu kedua & $0-3$ & $1-4$ & \\
$\quad$ Median & & & \\
$\quad$ Rentang & 1,5 & 2 & 0,011 \\
Minggu keempat & $0-2$ & $1-4$ & \\
$\quad$ Median & Rentang & & \\
\hline
\end{tabular}

Keterangan: *berdasarkan Uji Mann Whitney LFO=lem fibrin otologus derajat: $0=$ tidak ada pembuluh darah; $1=$ ada satu pembuluh darah; $2=$ ada dua pembuluh darah; $3=$ ada tiga pembuluh darah; 4=tiga pembuluh darah atau lebih 


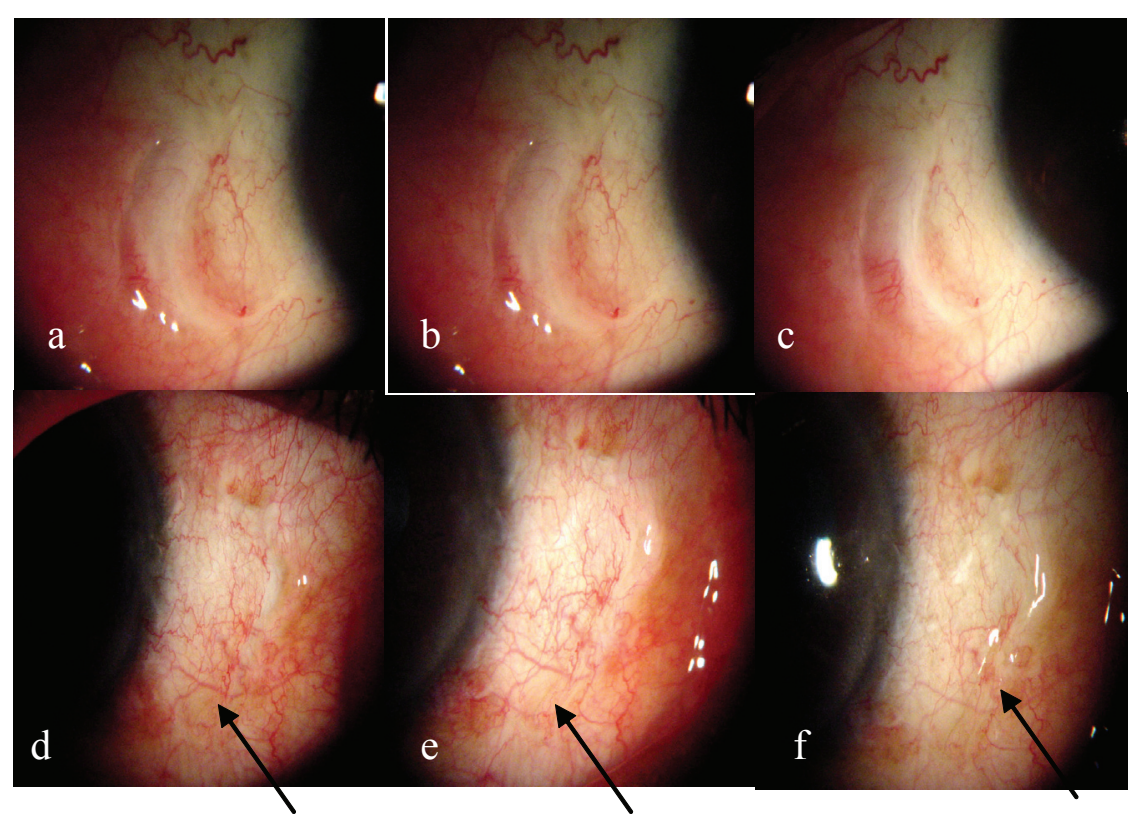

\section{Gambar Foto Pemantauan Hiperemis Pascabedah}

Foto a-c: Penderita X kelompok LFO (a. minggu pertama, b. minggu kedua, c. minggu keempat); Foto d-f: Penderita Y kelompok jahitan (d. minggu pertama, e. minggu kedua, f. minggu keempat)

Lem fibrin bersifat sebagai agen hemostatik, faktor koagulasi, dan perekat jaringan. Fibrinogen yang kemudian diubah menjadi fibrin merupakan matriks penyokong dan secara aktif merekrut sel yang berperan pada proses adhesi, migrasi, dan proliferasi yang diperlukan pada penyembuhan luka. Trombin merupakan enzim yang utama pada kaskade koagulasi yaitu dapat mengubah fibrinogen menjadi fibrin. Trombin merupakan regulator inflamasi dan juga proses reparasi pada jaringan yang terluka. Trombin akan menstimulasi dan meregulasi aktivitas sel yang terlibat dalam proses inflamasi dan proliferasi, namun trombin sendiri dapat bersifat sebagai agen antiinflamasi yang terjadi akibat pelepasan nitrit oksid (NO) sehingga menginhibisi adhesi monosit dengan sel endotel dan menghambat agregasi trombosit. Sifat trombin yang bertolak belakang tersebut terjadi untuk tetap menjaga keseimbangan proses fase inflamasi pada penyembuhan luka. ${ }^{7}$ Pada penelitian ini didapatkan hasil derajat hiperemis yanglebih kecil padakelompokLFOdibandingkan dengan kelompok jahitan pascabedah pterigium yang sesuai dengan sifat dan aktivitas lem fibrin dalam proses penyembuhan luka.

Keadaan inflamasi ini merupakan salah satu faktor yang menentukan hasil tindakan tandur konjungtiva bulbi pada pembedahan pterigium. Tindakah bedah pterigium menggunakan jahitan menimbulkan reaksi inflamasi yang lebih lama terjadi dibandingkan dengan teknik lem fibrin. ${ }^{2-5}$ Penggunaan lem fibrin juga dapat menurunkan angka kejadian rekurensi pascabedah pterigium. Ratnalingam dkk. ${ }^{4}$ melaporkan angka kejadian rekurensi yang lebih rendah pascabedah pterigium menggunakan lem fibrin (Tisseel) dibandingkan dengan menggunakan jahitan. Penelitian tersebut juga menunjukkan penempelan tandur pada dasar sklera yang lebih cepat dengan penggunaan lem fibrin akan mengurangi inflamasi pascabedah.

Faktor yang berperan terhadap keberhasilan teknik penempelan tandur konjutiva bulbi ini antara lain tandur harus setipis-tipisnya tanpa mengikutsertakan jaringan tenon, kedua jaringan harus terpapar serta menempel dengan rapat dan erat sehingga proses penyatuan kedua jaringan dan vaskularisasi dapat berjalan dengan baik. ${ }^{1}$ Mutiara $^{13}$ sudah melaksanakan penelitian yang melihat celah luka dan penyembuhan luka secara histologis antara teknik LFO dan teknik jahitan pada tandur konjungtiva kelinci, dan didapatkan hasil celah luka antara tandur konjungtiva bulbi dan lapisan sklera di bawahnya pada teknik LFO lebih kecil daripada teknik jahitan. Penyembuhan luka pun didapatkan lebih cepat pada kelompok yang menggunakan teknik LFO bila dibandingkan dengan kelompok yang memakai teknik jahitan.

Pudjiastuti $^{8}$ telah melakukan penelitian pada 
pembedahan pterigium menggunakan lem fibrin dan jahitan dan didapatkan hasil kelompok yang menggunakan lem fibrin mempunyai perlekatan yang lebih baik pada hari pertama dan minggu pertama pascabedah bila dibandingkan dengan kelompok yang menggunakan jahitan.

Lem fibrin komersial ternyata mempunyai kadar fibrinogen dan trombin tertentu yang telah terstandarisasi, sedangkan LFO bergantung pada keadaan penderita itu sendiri. ${ }^{7}$ Pada penelitian ini semua subjek penelitian yang menggunakan LFO tidak memiliki kelainan hemostasis (memiliki kadar fibrinogen, PT, dan aPTT yang normal) sehingga diharapkan akan menghasilkan kadar fibrinogen dan trombin optimal untuk membuat LFO yang dapat dipergunakan untuk melekatkan tandur konjungtiva bulbi pada waktu pembedahan pterigium.

Simpulan, penggunaan lem fibrin otologus untuk melekatkan tandur konjungtiva bulbi pada pembedahan pterigium inflamasi menghasilkan derajat hiperemis yang lebih kecil dibandingkan dengan penggunaan jahitan. Disarankan teknik LFO dapat digunakan sebagai pengganti teknik jahitan dan diperlukan penelitian jangka panjang untuk memantau tumbuh ulang.

\section{Daftar Pustaka}

1. Tan DTH. Pterygium. Dalam: Holland EJ, Mannis MJ, penyunting. Ocular surface disease medical and surgical management. New York: Springer Verlag; 2002. hlm. 65-89.

2. Hall RC, Logan AJ, Wells AP. Comparison of fibrin glue with sutures for pterygium excision surgery with conjunctival autografts. Clin Experimental Ophthalmol. 2009;37:584-9.

3. Ozdamar Y, Mutevelli S, Han U, Ileri D, Onal B, Ilhan O, dkk. A comparative study of tissue glue and vicryl suture for closing limbal-conjuctival autografts and histologic evaluation after pterygium excision. Cornea. 2008;27:552-8.

4. Ratnalingam V, Lim A, Leong NG, Taharin R, John E. Fibrin adhesive is better than sutures in pterygium surgery. Cornea. 2010;29:1-5.

5. Rollon $\mathrm{M}$, Gonzalez $\mathrm{P}$, Omarrementeria S, Rodriguez M, Hernandez P, Moreno J. Pterygium surgery: comparative study of conjuctival autograft with suture versus fibrin adhesive. Arch Sos Esp Ophthalmol. 2009;84:179-84.

6. Bahar I, Weinberger D, Dan G, Avisar R. Pterygium surgery: fibrin glue versus vicryl sutures for conjunctival closure. Cornea. 2006;25:1168-72.

7. Eyrich D, Gopferich A, Blunk T. Fibrin in tissue engineering. Advances in experimental medicine and biology. [diunduh 31 Maret 2009]. Tersedia dari: http://www. springerlink.com.www.ezlip.ukm.my/ content/g404715534365308/fulltext.pdf.

8. Pudjiastuti I. Efek fibrin glue terhadap attachment dan contact inhibition pada pembedahan pterigium dengan teknik tranplanstasi jaringan konjungtiva limbus [tesis]. Jakarta: Universitas Indonesia; 2002.

9. Koranyi G, Seregard S, Kopp ED. Cut and paste: a no suture, small incision approach to pterygium surgery. $\mathrm{Br} \mathrm{J}$ Ophthalmol. 2004;88:911-4.

10. Chan SM, Boishjoly H. Advances in the use of adhesives in opthtalmology. Curr Opin Ophthalmol. 2004;15:305-10.

11. Panda A, Kumar S, Kumar A, Bansal R, Bhartiya S. Fibrin glue in ophthalmology. Indian J Ophthalmol. 2009;57:371-9.

12. Enus S, Zamalek N, Kartiwa A. Teknik lem fibrin otologus pada cangkok konjungtiva bulbi mata kelinci. MKB. 2009;41:169-73.

13. Mutiara G. Perbandingan gambaran histologis penyembuhan luka antara teknik lem fibrin otologus dan jahitan pada cangkok konjungtiva kelinci [tesis] Bandung: Universitas Padjadjaran; 2007.

14. Putri NLHE. Perbandingan derajat rasa nyeri dan hiperemis pascatandur konjungtiva bulbi antara teknik lem fibrin otologus dan teknin jahitan pada operasi pterigium [tesis] Bandung: Universitas Padjadjaran; 2010.

15. Saxena S, Jain P, Shukla J. Preparation of two component fibrin glue and its clinical evaluation in skin grafts and flaps. Indian $\mathrm{J}$ Plastic Surg. 2003;36:14-7.

16. Srinivasan S, Dollin M, McAllum P, Berger Y, Rootman DS, Slomovic AR. Fibrin glue versus sutures fot attaching the conjunctival autograft in pterygium surgery: a prospective abserver masked clinical trial. $\mathrm{Br} \mathrm{J}$ Ophthalmol. 2009;93:215-8. 